
\title{
28 Research Square \\ Hyperuricemia Resistant to a Xanthine Oxidase Inhibitor, Topiroxostat: a Case Report
}

\section{Takahide Kimura}

International University of Health and Welfare: Kokusai Iryo Fukushi Daigaku

\section{Seiki Yamada}

International University of Health and Welfare: Kokusai Iryo Fukushi Daigaku

\section{Masayuki Tanemoto ( $\square$ mtanemoto-tky@umin.ac.jp)}

International University of Health and Welfare: Kokusai Iryo Fukushi Daigaku https://orcid.org/00000002-7933-6978

\section{Research Article}

Keywords: Chronic kidney disease, Gout, Hyperuricemia, Xanthine oxidase

Posted Date: July 14th, 2021

DOl: https://doi.org/10.21203/rs.3.rs-538083/v1

License: @ (i) This work is licensed under a Creative Commons Attribution 4.0 International License. Read Full License

Version of Record: A version of this preprint was published at SN Comprehensive Clinical Medicine on January 11th, 2022. See the published version at https://doi.org/10.1007/s42399-021-01081-1. 


\section{Abstract}

Hyperuricemia is a common complication of chronic kidney disease. Gout is a clinical symptom of hyperuricemia, and lowering serum uric acid concentration has been recommended to prevent its recurrence. We present a case whose hyperuricemia was resistant to a xanthine oxidase inhibitor, febuxostat, but not another inhibitor, topiroxostat, while both are presumed to inhibit the same enzymatic center of this rate-limiting enzyme for uric acid production. The different efficacy indicates that xanthine oxidase inhibitors are not interchangeable even among those acting on the same site of the enzyme.

\section{Introduction}

Hyperuricemia is a common complication of chronic kidney disease (CKD), because the kidney normally excretes around two-thirds of urate load [1,2]. Gout is a clinical symptom of hyperuricemia, which typically presents acute onset monoarthritis at the first metatarsophalangeal joint in the foot [3]. Lowering serum uric acid concentration (sUA) has been recommended to prevent the recurrence of gout, and pharmacological sUA-lowering therapy is generally required, because dietary and lifestyle optimization can reduce sUA only slightly [2,3]. Because of renal impairment, which weakens the efficacy of uricosuric agents, the agents that inhibit xanthine oxidase (XO), the rate-limiting enzyme for uric acid production, are generally used to lower sUA in hyperuricemic CKD patients [1,2]. In this report, we present a case whose hyperuricemia was resistant to a XO inhibitor, febuxostat, but not another inhibitor, topiroxostat, while both are presumed to inhibit the same enzymatic center of XO.

\section{Case Report}

An 80-year-old man with chronic kidney disease (CKD) stage G4 had a gout attack, when his serum uric acid concentration (sUA) and creatinine concentration were 12.2 and $3.2 \mathrm{mg} / \mathrm{dL}$, respectively (Table 1). After the symptom of gouty arthritis was relieved by glucocorticoid therapy, sUA-lowering therapy by oral administration of topiroxostat was started. However, even 2 months after the dose of topiroxostat had been increased to $60 \mathrm{mg} /$ day, sUA did not decrease (Fig. 1); it was $10.8 \mathrm{mg} / \mathrm{dL}$ while it had been around $10.5 \mathrm{mg} / \mathrm{dL}$ before the gout attack. Then, febuxostat $40 \mathrm{mg} / \mathrm{day}$ was substituted for topiroxostat 60 $\mathrm{mg} /$ day. The substitution lowered sUA to $7.0 \mathrm{mg} / \mathrm{dL}$ by 1 month and further to $6.2 \mathrm{mg} / \mathrm{dL}$ by 2 months. During the treatment his serum creatinine concentration increased to $4.4 \mathrm{mg} / \mathrm{dL}$, but renal replacement therapy was not started. 
Table 1

Laboratory measurements at the gout attack

\begin{tabular}{|ll|}
\hline Blood cells & Serum chemistry \\
WBC $\left(10^{3} / \mu \mathrm{L}\right) 5.8(3.6-8.0)$ & Total protein $(\mathrm{g} / \mathrm{dL}) 7.5(6.5-8.0)$ \\
$\mathrm{RBC}\left(10^{6} / \mu \mathrm{L}\right) 3.43(4.1-5.6)$ & Albumin $(\mathrm{g} / \mathrm{dL}) 4.3(3.8-4.6)$ \\
$\mathrm{Hb}(\mathrm{g} / \mathrm{dL}) 11.1(13.0-18.0)$ & BUN $(\mathrm{mg} / \mathrm{dL}) 79.9(8.0-20.0)$ \\
$\mathrm{Plt}\left(10^{5} / \mu \mathrm{L}\right) 1.25(1.2-4.0)$ & Creatinine $(\mathrm{mg} / \mathrm{dL}) 3.2(0.6-1.2)$ \\
& Uric acid $(\mathrm{mg} / \mathrm{dL}) 12.2(3.0-7.0)$ \\
& Sodium $(\mathrm{mM} / \mathrm{L}) 140(136-146)$ \\
& Potassium $(\mathrm{mM} / \mathrm{l}) 4.5(3.7-4.8)$ \\
& Chloride $(\mathrm{mM} / \mathrm{l}) 106(98-108)$ \\
\hline Normal ranges are shown in parentheses. & \\
\hline BUN, blood urea nitrogen; $\mathrm{Hb}$, hemoglobin; Plt, platelet; $\mathrm{RBC}$, red blood cell; WBC, white blood cell. \\
\hline
\end{tabular}

\section{Discussion}

This report presented a case of hyperuricemia, which was resistant to a XO inhibitor, topiroxostat, but not another inhibitor, febuxostat. The different efficacy indicates that $X O$ inhibitors are not interchangeable even among those acting on the same site of $\mathrm{XO}$ and that it is worth to try other inhibitors when one inhibitor is ineffective.

Topiroxostat is presumed to inhibit $\mathrm{XO}$ by forming a tight complex with molybdenum at the enzymatic center $[4,5]$. Febuxostat is also presumed to inhibit the same enzymatic center [6]. It was reported that topiroxostat $60 \mathrm{mg} /$ day provided sUA-lowering efficacy as well as febuxostat $40 \mathrm{mg} /$ day in CKD patients [7]. It was also reported that topiroxostat $20 \mathrm{mg} /$ day lowered sUA in most of the patients even with advanced CKD [8]. Thus, irrespective the stage of CKD, topiroxostat $60 \mathrm{mg} /$ day is expected to lower sUA. However, while febuxostat $40 \mathrm{mg} /$ day lowered the sUA of the present case, topiroxostat $60 \mathrm{mg} /$ day did not lower the sUA; the level of sUA 2 months after the therapy by topiroxostat $60 \mathrm{mg} /$ day did not differ from that before the gout attack.

The clinical course indicated that topiroxostat did not inhibit the $\mathrm{XO}$ of the present case while febuxostat did. We did not measure the blood concentration of topiroxostat and could not clarify whether topiroxostat was delivered to the XO. The topiroxostat resistance, however, is presumed to be attributable to either (i) topiroxostat was not delivered to the XO or (ii) the delivered topiroxostat did not inhibit the XO. 
Some genetic mutation in either the topiroxostat transporters or the $\mathrm{XO}$ of the present case would have made the XO not inhibitable by topiroxostat.

In summary, XO inhibitors are not interchangeable even among those blocking the same site of XO. Their efficacy will differ between individuals depending on their delivery system and affinity for XO in each individual. Thus, it is worth to try other inhibitors when one inhibitor is ineffective.

\section{Declarations}

\section{Authors' Contributions}

T.K.: data acquisition and manuscript writing. S.Y.: data acquisition. M.T.: concept and manuscript writing.

\section{Compliance with Ethical Standards}

Conflict of interest: The authors declared that they have no conflict of interests.

Ethical approval: This article does not contain any studies with human participants performed by any of the authors.

Informed consent: Informed consent was obtained from the patient reported.

\section{References}

1. Johnson RJ, Bakris GL, Borghi C, Chonchol MB, Feldman D, Lanaspa MA, et al. Hyperuricemia, Acute and Chronic Kidney Disease, Hypertension, and Cardiovascular Disease: Report of a Scientific Workshop Organized by the National Kidney Foundation. Am J Kidney Dis. 2018;71:851-65.

2. Vargas-Santos AB, Neogi T. Management of Gout and Hyperuricemia in CKD. Am J Kidney Dis. 2017;70:422-39.

3. Richette P, Bardin T. Gout. Lancet. 2010;375:318-28.

4. Okamoto K, Matsumoto K, Hille R, Eger BT, Pai EF, Nishino T. The crystal structure of xanthine oxidoreductase during catalysis: implications for reaction mechanism and enzyme inhibition. Proc Natl Acad Sci U S A. 2004;101:7931-6.

5. Matsumoto K, Okamoto K, Ashizawa N, Nishino T. FYX-051: a novel and potent hybrid-type inhibitor of xanthine oxidoreductase. J Pharmacol Exp Ther. 2011;336:95-103.

6. Okamoto K, Eger BT, Nishino T, Kondo S, Pai EF, Nishino T. An extremely potent inhibitor of xanthine oxidoreductase. Crystal structure of the enzyme-inhibitor complex and mechanism of inhibition. $J$ Biol Chem. 2003;278:1848-55.

7. Nagaoka Y, Tanaka Y, Yoshimoto H, Suzuki R, Ryu K, Ueda M, et al. The effect of small dose of topiroxostat on serum uric acid in patients receiving hemodialysis. Hemodial Int. 2018;22:388-93. 
8. Sun SS, Zhang DH, Shi Y, Lin CJ, Lin JY. Efficacy and safety of urate-lowering treatments in patients with hyperuricemia: A comprehensive network meta-analysis of randomized controlled trials. J Clin Pharm Ther. 2020;45:729-42.

\section{Figures}

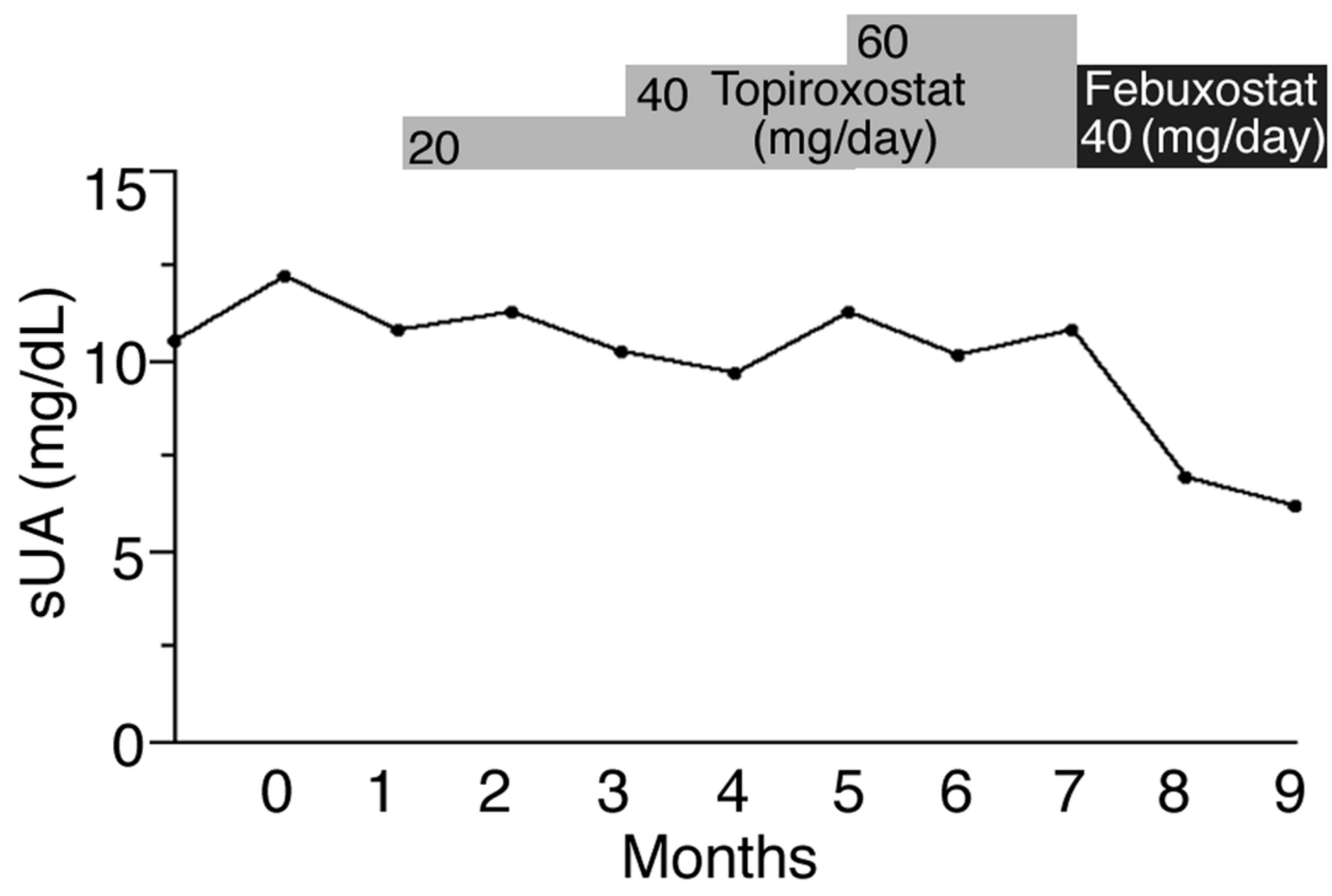

Figure 1

Levels of sUA. The horizontal axis indicates months after the gout attack. sUA, serum uric acid concentration. 